\title{
DETECTION OF NITRITE IN PROCESSED AND READY TO EAT MEAT PRODUCTS IN AND AROUND KOLKATA
}

\author{
A. DHARMSINGH, C. DEBNATH* AND A. BANERJEE ${ }^{1}$ \\ Department of Veterinary Public Health \\ West Bengal University of Animal and Fishery Sciences \\ Kolkata-700 037, India
}

\begin{abstract}
In processed meat items, nitrites are common ingredients used as preservatives as well as to increase the aesthetic value of the food items. However, its regular and excessive intake may impair oxygen transportation, cause cancer, type I diabetes in children, irritate the digestive system, abdominal pain, damage to blood cells and blood vessels, difficulty breathing etc. The present study was undertaken with an objective to find out the level of nitrites present in various processed and ready to eat meat products namely Kabiraji, Nuggets, Pakodas, Sausages, Salami and Chicken Popcorn collected from different restaurants and retail outlets in and around Kolkata by using Ultra Violet spectrophotometer. Out of total 66 samples tested 6 samples of Kabiraji, 5 samples of chicken pakodas, 8 samples of nuggets, 3 samples of chicken burgers, 3 samples of salamis and 3 samples of chicken popcorns were found to be loaded with more than the acceptable limit of nitrites in them, which is highly alarming from the public health point of view.
\end{abstract}

Key words: Curing, Fast food, Meat foods, Preservatives, Spectrophotometry

In India, consumption of ready to eat meat products are increasing tremendously due to rapid urbanization, modern life style, increased monthly income and easy accessibility of fast food items (Manohar et al., 2005). Preservatives or additives like sodium nitrite $\left(\mathrm{NaNO}_{2}\right)$, sodium nitrate $\left(\mathrm{NaNO}_{3}\right)$, potassium nitrate $\left(\mathrm{KNO}_{3}\right)$, potassium nitrite $\left(\mathrm{KNO}_{2}\right)$, or their combinations are commonly added to meat products for extending the shelf life. These preservatives serve a good purpose to the products by giving it a pinkish-reddish colour and antioxidant effects. They also prevent the growth of Clostridium botulinum, have anti-microbial action,

*Corresponding Author

${ }^{1}$ Department of Veterinary Microbiology, West Bengal University of Animal and Fishery Sciences, Kolkata-700037 
develop cured meat flavor, and retard development of rancidity and off-odors during storage (Zanardi et al., 2002).

However, these preservatives can cause serious health damages to the consumers by creating nitrosamines (highly carcinogenic substances) when they combine with secondary and tertiary amines present in the meat (Greer and Shannon, 2005). They can also combine with haemoglobin creating methaemoglobin, which damages the blood oxygen transport and in long term it causes methemoglobinemia mainly in children (Greer and Shannon, 2005), causing face redness, vasodilatation, cyanosis, gastrointestinal discomfort, vomiting and headache (Harada and Silva, 2002). Regular consumption of processed meat (containing nitrite) elevated the risks of various cancers in humans including that of thyroid gland, ovary, kidney and bladder (Ferrucci et al., 2010; Kilfoy et al., 2011; Dellavalle et al., 2013).

The FDA regulates the allowable levels of inorganic nitrite in foodstuffs (FDA, 2003), and they recommended that the level of sodium nitrite should not exceed $200 \mathrm{ppm}$ in the finished product. Noncompliance of maintenance of this level in any of the food items which are used to be taken by the consumers readily and regularly may lead to different health hazards. Therefore, the purpose of the present study was to find out the amount of nitrite present in different ready-to-eat meat products which are being consumed by people in and around Kolkata.

\section{MATERIALS AND METHODS}

The study was conducted following the guidelines as prescribed by Food Safety Standards Authority of India (FSSAI, 2012).

\section{Reagents used and their methods of preparation:}

(a) Alumina cream: Saturated solution of potassium aluminium sulphate was prepared and ammonia was added slowly to make the $\mathrm{pH} 7.0$.

(b) $\mathrm{N}-\mathrm{n}$ a p thyet hy le nedia mine dihydochloride solution: $0.1 \%$ in distilled water.

(c) Arsenilic acid monohydrate: $0.1 \%$ in $5 \mathrm{M} \mathrm{HCl}$.

(d) Standard nitrite solution: 10mg pure sodium nitrite was dissolved in distilled water and diluted to $100 \mathrm{~mL}$ volumetric flask that constitutes the solution ' $A$ '. $5 \mathrm{~mL}$ of solution ' $\mathrm{A}$ ' was taken and transferred to a $1000 \mathrm{~mL}$ volumetric flask and adjusted to that volume to prepare solution ' $\mathrm{B}$ '. Series was prepared by pipetting $4 \mathrm{~mL}, 5$ $\mathrm{mL}, 6 \mathrm{~mL}$ and likewise up to $15 \mathrm{~mL}$ in 12 different volumetric flasks from solution 'B'. These standard solutions now contain 2 microgram, 2.5 microgram, 3 microgram and so on up to 7.5 microgram of nitrite respectively in each flask.

Collection and preparation of the samples: Sixty six samples of ready to eat meat products were collected from 12 different restaurants and retail outlets mostly in the morning in and around of 
Kolkata. Firstly, each sample was properly macerated or homogenized and $5 \mathrm{gm}$ of that sample was taken in a $150 \mathrm{~mL}$ beaker. An amount of $50 \mathrm{~mL}$ distilled water was then added to it and heating was done at $80^{\circ} \mathrm{C}$ for 10 to 15 minutes with continuous stirring. To it $20 \mathrm{~mL}$ alumina cream was added and after proper mixing whole content was transferred to a $100 \mathrm{~mL}$ volumetric flask. It was diluted with distilled water to the mark. Filtering was done with the Whatman No. 4 filter paper after washing the filter papers several times by distilled water to eliminate any residual nitrite in them. Initial $10 \mathrm{~mL}$ of the filtrate was discarded.

Methodology: The following methodology was undertaken as per the guidelines given by Food Safety Standards Authority of India (FSSAI, 2012).

Determination of nitrite: $10 \mathrm{~mL}$ filtrate was taken in a $50 \mathrm{~mL}$ volumetric flask and to it $2 \mathrm{~mL}$ arsenelic acid solution was added. After mixing, it was left for 5 minutes and $2 \mathrm{~mL} \mathrm{~N}$-napthyethylenediamine solution was added and mixed. It was left for 10 minutes. If the solution was clear it was diluted to $50 \mathrm{~mL}$ distilled water and the absorbance was read at $538 \mathrm{~nm}$ using $1 \mathrm{~cm}$ cell. If the solution was cloudy, it was transferred to $100 \mathrm{~mL}$ separator and saturated with salt. It was then extracted with N-butanol using $20 \mathrm{~mL}, 15 \mathrm{~mL}$ and $5 \mathrm{~mL}$ and butanol extracts were passed through cotton pledget (small flattened pad) in a funnel into dry $50 \mathrm{~mL}$ calibrated flask.
Dilution was done to volume by N-butanol and absorbance was read at $545 \mathrm{~nm}$ in a $1 \mathrm{~cm}$ cell.

Preparation of standard curve: Series of 50 $\mathrm{mL}$ volumetric flask were taken and pippeting was done with standard solutions of sodium nitrite containing 2-15 microgram of nitrite nitrogen and final volume of $50 \mathrm{~mL}$ was made by using distilled water and colour was developed by above procedure. Absorbance was read at $545 \mathrm{~nm}$ and standard curve was plotted (FAO, 1980).

\section{RESULTS}

Standard curve of standard nitrite solutions containing 2-15 microgram of nitrite nitrogen (40-300ppm respectively) was prepared on a graph (Table 1 and Chart 1). In the said curve it was evident that the concentration of the standard solution that contains 10 microgram $/ 50 \mathrm{~mL}$ corresponds to $200 \mathrm{ppm}$ of nitrites, which shows the absorbance unit (AU) value of 0.0876 in the spectrophotometer. Therefore, the AU value of 0.0876 was considered as the highest acceptable limit of nitrite that may be safe for the consumers (FDA, 2003). Results obtained from different food samples were then compared with this safe limit and while compared it was observed that $6 / 11(54.5 \%)$ kabiraji, 5/11 (45.4\%) chicken pakoda, 8/11 (72.7\%) nuggets, 3/ $11(27.2 \%)$ chicken burger, 3/11 (27.2\%) salami and again $3 / 11(27.2 \%)$ chicken popcorn samples were found to contain more than acceptable limit of nitrites in 
them. The amount of nitrites present in $1 / 11(9.0 \%)$ each from kabiraji, chicken pakoda, nuggets, chicken burger, salami and 2/11 (18.1\%) chicken popcorn samples were statistically highly significant level $(\mathrm{p}<0.01)$ as shown in Table 2.

Table 1. Different gradients of standard sodium nitrite solutions and their corresponding ppm values

\begin{tabular}{ccc}
\hline $\begin{array}{c}\text { Sl. } \\
\text { No. }\end{array}$ & $\begin{array}{c}\text { Standard solution concentration } \\
\text { of sodium nitrite }\end{array}$ & $\begin{array}{c}\text { Reading } \\
\text { in ppm }\end{array}$ \\
\hline 1. & $2 \mathrm{microgram} / 50 \mathrm{~mL}$ & 40 \\
2. & $3 \mathrm{microgram} / 50 \mathrm{~mL}$ & 60 \\
3. & $4 \mathrm{microgram} / 50 \mathrm{~mL}$ & 80 \\
4. & $5 \mathrm{microgram} / 50 \mathrm{~mL}$ & 100 \\
5. & $6 \mathrm{microgram} / 50 \mathrm{~mL}$ & 120 \\
6. & $7 \mathrm{microgram} / 50 \mathrm{~mL}$ & 140 \\
7. & $8 \mathrm{microgram} / 50 \mathrm{~mL}$ & 160 \\
8. & $9 \mathrm{microgram} / 50 \mathrm{~mL}$ & 180 \\
9. & $10 \mathrm{microgram} / 50 \mathrm{~mL}$ & 200 \\
10. & $11 \mathrm{microgram} / 50 \mathrm{~mL}$ & 220 \\
11. & $12 \mathrm{microgram} / 50 \mathrm{~mL}$ & 240 \\
12. & $13 \mathrm{microgram} / 50 \mathrm{~mL}$ & 260 \\
13. & $14 \mathrm{microgram} / 50 \mathrm{~mL}$ & 280 \\
14. & $15 \mathrm{microgram} / 50 \mathrm{~mL}$ & 300 \\
\hline
\end{tabular}

Table 2. Meat samples with their readings (Absorbance Units- AU) in spectrophotometer

\begin{tabular}{ccccccc}
\hline Sl. No. & Kabiraji & $\begin{array}{c}\text { Chicken } \\
\text { Pakodas }\end{array}$ & Nuggets & Chicken Burger & Salami & $\begin{array}{c}\text { Chicken } \\
\text { Popcorn }\end{array}$ \\
\hline 1. & 0.0825 & 0.0725 & 0.0896 & 0.0952 & $0.0986^{*}$ & 0.0845 \\
2. & 0.0913 & 0.0820 & 0.0835 & 0.0841 & 0.0745 & 0.0820 \\
3. & 0.0922 & 0.0890 & 0.0721 & 0.0825 & 0.0785 & $0.0986^{*}$ \\
4. & 0.0895 & 0.0896 & 0.0886 & 0.0928 & 0.0745 & $0.0989^{*}$ \\
5. & 0.0789 & 0.0909 & 0.0885 & 0.0654 & 0.0734 & 0.0845 \\
6. & 0.0820 & 0.0820 & 0.0784 & 0.0628 & 0.0625 & 0.0854 \\
7. & $0.0952^{*}$ & 0.0845 & $0.1124^{*}$ & $0.0971^{*}$ & 0.0786 & 0.0897 \\
8. & 0.0700 & $0.1025^{*}$ & 0.0895 & 0.0723 & 0.0898 & 0.0839 \\
9. & 0.0926 & 0.0826 & 0.0913 & 0.0654 & 0.0939 & 0.0798 \\
10. & 0.0900 & 0.0921 & 0.0890 & 0.0756 & 0.0821 & 0.0732 \\
11. & 0.0752 & 0.0851 & 0.0920 & 0.0752 & 0.0854 & 0.0812 \\
\hline
\end{tabular}

$*(\mathrm{p}<0.01)$ 


\section{Chart 1. Standard curve prepared by comparing the ppm values of the standard solutions with their corresponding AU values in spectrophotometer}

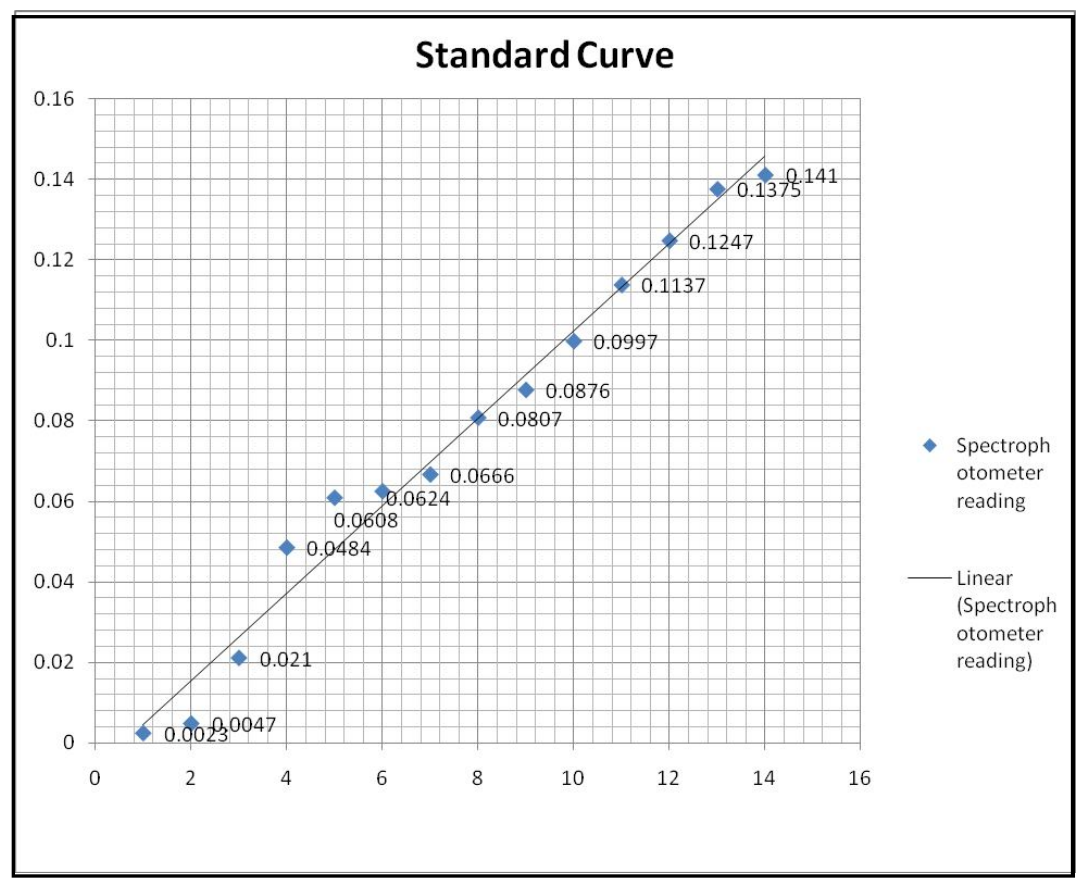

\section{DISCUSSION}

The presence of nitrite in foods and its ill effects on consumers is a debatable issue since last many years. One school of thought explained it as a harmful agent for human health whereas others denied it (Sindelar and Milkowski, 2011). However, the exact impact is debatable and not beyond doubt. Therefore, the findings of the present study where $42.4 \%(28 / 66)$ of the total ready to eat meat food products that contains more than the permissible limit of the said chemical is alarming. Again, $10.6 \%(7 / 66)$ of the total samples where the amount of the preservative is significantly higher than the permissible limit; further demands a more serious attention of the food safety authorities in order to safeguard the general health of the consumers. Khodadady et al.(2012) from Birjand, Iran also reported the presence of nitrite residues in $10 \%$ of the total 120 sausage and salami samples tested containing more than the accepted national standard.

To conclude the findings of the present study, we can say that nitrates and nitrites may be a promising alternative for preservation of meat against different primitive preservative techniques. But, its ill health effects due to excessive consumption are not undoubtful. Therefore, 
it should be judiciously used by the food technologists and food retailers under the stringent supervision of the regulatory bodies.

\section{REFERENCES}

Dellavalle CT, Daniel CR, Aschebrook-Kilfoy B, Hollenbeck AR and Cross AJ et al., 2013. Dietary intake of nitrate and nitrite and risk of renal cell carcinoma in the NIH-AARP diet and health study. Br J Cancer, 108(1): 205

FAO Manuals of Food Quality Control 1980, 14 / 2, pp 27

FDA- Code of Federal Regulations, 2003. Title 21, Pts. 110-Current Good Manufacturing Practice in Manufacturing, Packing, or Holding Human Food, 170- Food Additives, and Section 172.177-Sodium nitrite used in processing smoked chub

Ferrucci LM, Sinha R, Ward MH and Graubard BI, 2010. Meat and components of meat and the risk of bladder cancer in the NIHAARP diet and health study. Cancer 116: 4345-4353

FSSAI, 2012. Manual of Methods of Analysis of Foods (Food Additives). Ministry of Health and Family Welfare, GOI, New Delhi, Sl No. 2.6, pp 33

Greer FR and Shannon M, 2005. Infant methemoglobinemia: the role of dietary nitrate in food and water. Pediatrics, 116: 784-786

Harada MM and Silva ML, 2002. Nitrito nitrato
Conflict of interest: Authors declare that there is no conflict of interest regarding the present research work.

segurança alimentar. Rev Nac Carne, São Paulo, 26(308): 105-106

Khodadady M, Shahryari T, Dorri H, Sharifzadah GR and Ziyazade A, 2012. Evaluation of nitrite in meat products (sausages and salami) are distributed in Birjand in 2012. Euro J Exp Bio, 2 (6): 2120-2124

Kilfoy BA, Zhang Y, Park Y and Holford TR, 2011. Dietary nitrate and nitrite and the risk of thyroid cancer in the NIH-AARP diet and health study. Int J Cancer, 129: 160-172

Manohar SS, Balasubramanyam BV and Sheshachala, 2005. Convenience Foods - Growth \& Prospects, Indian food Industry, Vol.24, No. 4, National Dairy Research Institute (NDRI), Southern campus

Sindelar JJ and Milkowski AL, 2011. Sodium nitrite in processed meat and poultry meats: A review of curing and examining the risk/benefit of its use. American Meat Sci Asso White Paper Series, 3: 114

Zanardi E, Dazzi G, Madarena G and Chizzolini R, 2002. Comparative study on nitrite and nitrate ions determination. Ann Fac Medic Vet di Parma, 22: 79-86

Article received on 12.04.2018 and accepted for publication on 20.05.2018 